Soil Science and Agricultural Engineering

Available online at http://zjar.journals.ekb.eg

http:/www.journals.zu.edu.eg/journalDisplay.aspx?Journalld=1\&queryType=Master

\title{
REMOVAL OF URANIUM AND ASSOCIATED ELEMENTS FROM SINAI WELLS WATER USING THE DRIED AND CHEMICALLY MODIFIED ORANGE PEELS
}

\author{
Abdelhalim M. Abdelhakim ${ }^{1 *}$, E.A.M. Awad ${ }^{2}$, I.R.Mohamed ${ }^{2}$ and Enas M. El-Sheikh ${ }^{1}$ \\ 1. Nuclear Materials Authority, PO. Box 530 El Maadi, Cairo, Egypt \\ 2. Soil Sci. Dept., Fac. Agric., Zagazig Univ., Egypt
}

Received: 01/12/2020 ; Accepted: 12/01/2021

\begin{abstract}
It is well known that the natural cellulose has low ionic exchange properties, due to its characterization by a small number of carboxylic groups. Incorporation of different functional groups can promote its ionic exchange capacity. In this work, modification of orange peel by treating with sodium hydroxide and amination, phosphoration and sulfonation. The different ion exchanger has been used to increase the ion exchange capacity of such materials, by developing their swelling properties and decreasing their lignin content. A maximum uranium uptake of $726 \mathrm{mg} / \mathrm{g}$ was observed at the obtained optimum conditions using modified resin (ion exchange No. VII). The latter (0.841: $0.420) \mathrm{mm}$ size orange peels were modified using a mixture of sulfonic and phosphoric acids. Ion exchange No. VII was used as the case study to remove uranium and associated elements from Sinai wells water. The main purpose of this work is to prepare different resins from the Egyptian plant waste. Orange peels were chosen because they are popular and widespread plant wastes in Egypt.
\end{abstract}

Key words: Uranium, orange peels, heavy meatls, adsorption.

\section{INTRODUCTION}

Nowadays, there is a great concern for caring about the environmental from industrial wastes and its hazardous effects on water and plants pollution and its consequent health impacts on the public. One of the problems in this respect is the presence of heavy metal ions such as $\mathrm{U}$, Th, $\mathrm{Hg}, \mathrm{Co}$, etc., which exist in wastewater effluents coming from different industries. The recovery of these strategic metals from waste streams is necessary due to their hazardous effect and to their inherent value (Gautam et al., 2014). Water pollution is generally due to the presence of dissolved inorganic and organic minerals found in domestic and industrial waters. Heavy metal ion pollutants in water result in ecological problems even at very low concentration which increased the need for materials that can provide efficient complexing potential toward these metal ions (Essawy and Ibrahim, 2004). Water

\footnotetext{
* Corresponding author: Tel.: +201208064521

E-mail address: abdelhalim2982@gmail.com
}

pollution might be also due to some physical factors such as turbidity, color, temperature, associated radioactivity, etc. (LalSrivastav and Ranjan, 2020)

Extraction of metals from their aqueous solutions and the corresponding separation methods have lately gained an increasing importance through transfer of metal ions from an aqueous phase to a solid phase (ion exchange resin). The main advantage of ion exchange resin that it doesn't suffer from any phase disengagement problems (phase separation) or reagent losses; both of them are considered the main troublesome inconveniences of solvent extraction (Ritcy and Ashbrook, 1982).

Numerous waste biomass sources are available and upon which several experimental adsorption studies were performed e.g. rice husk, cotton stalk, sawdust, peanut shells, corn cobs, etc. (Loizidou, 2015). 
Using agriculture waste as natural adsorbent would be greatly advantageous in a manner to benefit from their ligenocellulosic structure. Among these wastes, huge amounts of orange peels are annually produced and ligenocellulosic structure is greatly favorable for metal recovery. The latter can be realized through introduction of certain functional group, that would behave as ion exchanger. This function would includes group function as cation exchanger or groups function as anion exchanger. That can include many organic phosphorus and/or sulfur compounds and a various amines (Essawy and Ibrahim, 2004; Feng et al., 2009; Muhammad et al., 2012; Pankaj et al., 2012; El-Sheikh, 2013).

Orange peels is used to remove the metal ions such as; cadmium, lead, and copper from aqueous solutions (Feng and Guo, 2012; Abdelhafez and Jianhua, 2016; Amin et al., 2017) many previous works have revealed that physical and/or chemical activation lead to improving the adsorbent properties of the orange peels such as, porosity, surface area and increasing available active sites. Generally, the plant wastes give soluble organic compounds, these organic compounds need a high amount of oxygen to be soluble. Consequently, the oxygen would decrease and the aquatic plant would be become threaten. Therefore, the treatment of the plant wastes has become urgent to be used for removing the heavy metals from water with $\mathrm{K}_{2} \mathrm{CO}_{3}$ as a basic chemical activation element and potassium or sodium hydroxide environment friendly (Li et al., 2007).

Schiewer and Patil (2008) examined the native and protonated orange peel for their potentiality to remove $\mathrm{Pb}^{2+}$ ions from aqueous solution. The results found that protonated orange peels have shown highest loading capacity compared to native peels. This is due to the elimination of alkali and alkaline earth metal ions present in the native orange peels. Fourier transform infrared spectroscopy (FTIR) studies of protonated orange peels after adsorption of $\mathrm{Pb}^{2+}$ ions suggested that hydroxyl and carboxyl groups are major contributors in metal uptake. Ning-Chuan et al. (2010) studied the removal of $\mathrm{Cu}^{2+}$ ions by orange peel chemically modified with sodium hydroxide and calcium chloride. The modified adsorbent was successfully regenerated with $\mathrm{HCl}$ for five times with little loss in loading capacity. Liang et al. (2010) successfully demonstrated $\mathrm{K}^{+}$type and $\mathrm{Mg}^{2+}$ type orange peel for the removal of $\mathrm{Cu}^{2+}$ ions from aqueous solution and $\mathrm{K}^{+}$type orange peel showed the highest loading capacity compared to $\mathrm{Mg}^{2+}$ type adsorbent. In this regard orange peel modified with cross-linking reagent after alkali saponification used after different alkali saponification $\left(\mathrm{NaOH}, \mathrm{NH}_{4} \mathrm{OH}\right.$, and $\mathrm{Ca}(\mathrm{OH})_{2}$ and different acids $\left(\mathrm{C}_{6} \mathrm{H}_{6} \mathrm{O}_{7} \cdot \mathrm{H}_{2} \mathrm{O}, \mathrm{H}_{2} \mathrm{C}_{2} \mathrm{O}_{4}\right.$, and $\left.\mathrm{H}_{3} \mathrm{PO}_{4}\right)$ as biosorbents For $\mathrm{Co}^{+2}, \mathrm{Ni}^{+2}, \mathrm{Zn}^{+2}$ and $\mathrm{Cd}^{+2}$ from aqueous solution (Li et al., 2007 and 2008).

The aim of this work is to prepare different resins from the Egyptian plant wastes to fulfill the concepts arise in the scope of study. Orange peels were chosen because they are popular and widespread orange juice industry wastes in Egypt. Seven forms of resins were synthesized to study their potentiality to extract uranium. In addition, their durability, selectivity and their exposure to physical and chemical poising were consideraed. This work studied the potentiality of modified orange peels for enhancing or removing the uranium and associated heavy elements, such as $\mathrm{As}, \mathrm{Pb}$. ect. from ground water of two wells in Allouga area, South Western Sinai, Egypt.

\section{MATERIALS AND METHODS}

\section{Materials \\ Orange Peels Preparation}

The orange peels were washed with a tap water as well as distilled water several times to remove dirt and other contaminants then air dried for 4 days. The dried samples were ground properly using a mortar and pestle to obtain the powdered form ranging about (0.841: 0.420) $\mathrm{mm}$. The powder were stored in polyethylene bags.

\section{Preparation of synthetic solution}

Synthetic solution of uranium was prepared from its proper salt Uranyl a cetate. Solutions were thus prepared by dissolving analytical grade metal salt in distilled water to obtain accurate concentration in $(\mathrm{mg} / \mathrm{l})$ solution. Investigated solutions were prepared by dilution to obtain the required concentrations. The $\mathrm{pH}$ of 
these solutions was measured and adjusted at 4 and all the adsorption experiments were run at room temperature $\left(25 \pm 2{ }^{\circ} \mathrm{C}\right)$.

\section{Methods}

\section{Characterization of orange peels}

To achieve the chemical characterization of Egyptian orange peels (Citrus sinensis) a number of chemical analyses were done including the determination of moisture, ash, protein, lignin, fat and fiber as well as carbohydrate.

According to chemical analyses of orange peels wastes, it is mainly composed of carbohydrates, lignin and some structural proteins in different ratios (Table 1). To evaluate the investigated orange peels waste, a suitable sample was subjected to a chemical analyses to determine their major and trace components.

Results in Table 1 indicated that, the nutritional values for ash, protein, carbohydrates crud fiber and fats were $6.9 \%, 11.98 \%, 54.11 \%$, $15.1 \%$ and $0.35 \%$, respectively. Indicating that orange peels are good sources of nutrients and have high content of iron and manganes. It is important to mention herein that, the obtained data were in an agreement with results of AlSaadi et al. (2009) and Sulekha and Jaya (2018).

\section{Moisture content}

About $2 \mathrm{~g}$ of Egyptian orange peels were dried in an oven at $103 \pm 2^{\circ} \mathrm{C}$, till constant weight and the moisture content was then estimated by calculating the loss percent of the orange peels weight

\section{Ash content}

Ash content was estimated by burning orange peels samples contained in a porcelain crucible using a muffle furnace at $400^{\circ} \mathrm{C}$ for 30 minutes, then at $850^{\circ} \mathrm{C}$ for 45 minutes. Then ash percentage was calculated from the loss in weight according to Technical Association of the Pulp and Paper Industry TAPPI (1957) slandered methods.

\section{Determination of some organic constituent}

According to AOAC (1984) protein, fat, crude fiber and carbohydrate content were determined as follow: Proteins were determined using $\mathrm{CuSO}_{4} / \mathrm{TiO}_{2}$ mixed catalyst kjeldahl method 1988. The percentage of the nitrogen was determined using kejeldahal apparatus and the percentage of protein was calculated. Fat was carried out by using ether extract and gravimetric method. Crude fiberas obtained by digesting sample with $\mathrm{H}_{2} \mathrm{SO}_{4}$ and $\mathrm{NaOH}$ followed by incinerating in muffle furnace at $550^{\circ} \mathrm{C}$ for $4 \mathrm{hr}$. Carbohydrate content was calculated from the difference of $100-$ [moisture $(\%)+$ ash $(\%)+$ protein $(\%)+$ fat $(\%)$ + fibre (\%). Elements determination $\mathrm{Ni}, \mathrm{Cu}, \mathrm{Fe}$, $\mathrm{Zn}, \mathrm{Mn}$. contents were determined using atomic absorption spectroscopy (Perken-Elmer 5000). Phosphorous and sulfur contents in each composite was estimated according to Cotteni (1980).

\section{The chemical composition of underground water wells}

Water sample was collected three times throughout the year from Alluga wells. Sample was subjected to complete chemical analysis for cations and anions content (Table 2).

\section{Preparation of modified resins}

The following modification processes were used on orange peels to increase their ability for adsorbing uranium:

\section{Preparation of Orange peels as ion exchanger No.1}

The powder of the peels was used without any modification or additions.

\section{Preparation of ion exchanger No. II}

Twenty $\mathrm{g}$ of dry ground orange peels $(0.841$ : $0.250) \mathrm{mm}$ were shaked under refluxed with $150 \mathrm{ml}$ of sodium hydroxide $6 \%(W / V)$ for 3 hours. The residue was filtered off and washed by distilled water until no color with phenol phthalein (ph.ph.) at $\mathrm{pH} 7$ and finally washed with distilled water. The residue was dried giving the ion exchanger No.II, (El-Sheikh, 2006).

\section{Preparation of ion exchanger No. III}

Ten $\mathrm{g}$ of dry ground orange peels $(0.841$ : $0.250) \mathrm{mm}$ size were refluxed with $150 \mathrm{ml}$ of sodium hydroxide $6 \%(W / V)$ for 3 hours. The residue was filtered off and washed by distilled water until no color with phenol phthalein (ph.ph.). The alkali pretreatment orange peels 
Table 1. Average chemical characterization of organic and mineral constituents of Egyptian orange peels (Citrus sinensis)

\begin{tabular}{lcc}
\hline Constituent name & \multicolumn{2}{c}{ Organic constituents } \\
\hline Organic constituents & Investigated orange peels & Published data* \\
\hline Moisture (\%) & 10.00 & 9.2 \\
Ash (\%) & 6.90 & 7.8 \\
Protein (\%) & 11.98 & 12.43 \\
Carbohydrate (\%) & 54.11 & 52.9 \\
Crude fiber (\%) & 15.1 & 14.17 \\
Fat (\%) & 0.35 & 0.20 \\
& Mineral composition & \\
Mineral elements & Investigated orange peels $(\boldsymbol{\mu g} / \mathbf{g})$ & Published data** $(\boldsymbol{\mu g} / \mathbf{g})$ \\
Iron & 111 & 125 \\
Manganes & 76 & 88 \\
Zinc & 15 & 13 \\
Nickel & 2 & 1.6 \\
Copper & 2 & 1.3 \\
\hline
\end{tabular}

* Sulekha and Jaya (2018)

**Al-Saadi et al. (2009)

Table 2. Chemical analyses of underground water samples

\begin{tabular}{|c|c|c|c|c|c|c|c|c|c|c|c|}
\hline \multirow[t]{2}{*}{$\overline{\text { Well No. }}$} & \multirow[t]{2}{*}{ pH } & \multirow{2}{*}{$\begin{array}{c}\text { EC } \\
\mathrm{dS} / \mathrm{m}\end{array}$} & \multicolumn{4}{|c|}{ Cations mmocl/l } & \multicolumn{5}{|c|}{ Anions mmocl/l } \\
\hline & & & & $\mathrm{Mg}^{+2}$ & & & $\mathrm{~K}^{+} \mathrm{Co}_{3}{ }^{-2}$ & $\overline{\mathrm{HC}}$ & & $\mathrm{CL}^{-}$ & $\mathrm{SO}_{4}{ }^{2-}$ \\
\hline 1 & 7.5 & 2 & 13.9 & 0.153 & 3.12 & 3.05 & . & 3.03 & 9.4 & 7 & \\
\hline 2 & 7.4 & & 49.13 & 0.153 & 2.1 & 2.1 & - & 3.03 & 6.37 & 4 & \\
\hline
\end{tabular}


they were refluxed with $35 \mathrm{ml}$ of tri-ethyl amine and $46 \mathrm{ml}$ epichorohydrine. The latter were refluxed for $4 \mathrm{hr}$., at $55^{\circ} \mathrm{C}$. The residue was dried giving the ion exchanger No.III (ElSheikh, 2006)

\section{Preparation of ion exchanger No. IV}

Ten $g$ of dry ground orange peels $(0.841$ : $0.250) \mathrm{mm}$ size were refluxed with $35 \mathrm{ml}$ of triethyl amine and $46 \mathrm{ml}$ epichorohydrine. The mixture was refluxed for $4 \mathrm{hr}$., at $55^{\circ} \mathrm{C}$. The residue was dried giving the ion exchanger No. IV, (Orabi et al., 2016).

\section{Preparation of ion exchangers No. V}

The phosphorylated orange peels were carried out according to El-Sheikh (2006). A dry tow $\mathrm{g}$ of orange peels were alkalized with $\mathrm{NaOH}$ pretreated as the procedure mentioned above. They were refluxed in $40 \mathrm{ml}$ pyridine for one hour, then $5 \mathrm{ml}$ of phosphorus oxychloride $\mathrm{POCl}_{3}$ was added, which diluted by $10 \mathrm{ml}$ of 1,2-Dichloroethane that was added drop by drop with stirring the mixture for two hours with reflux. The mixture was cooled and poured into ice water, filtered and washed with dilute $\mathrm{HCl}$ $(5 \% ; V / V)$ till no odors of pyridine. The mixture was washed with distilled water till no color with methyl orange. The prepared ion exchangers No. V were dried giving celluloseoxyphosphoric acid composites.

\section{Preparation of ion exchangers No. VI}

Tow $g$ of dry orange peels were soda pretreated as the procedure mentioned above. They were refluxed in $40 \mathrm{ml}$ pyridine for one hour. A mixture of $5 \mathrm{ml}$ chlorosulfonic acid diluted with $10 \mathrm{ml}$ of 1,2-Dichloroethane were added. This reaction of the mixture was refluxed for two hours, filtered and washed with dilute $\mathrm{HCl}(5 \% ; V / V)$ till no odors of pyridine. The mixture was washed with distilled water till no color with methyl orange and proceeded as above to yield a prepared ion exchangers No. VI. They were dried giving cellulose - sulfonic acid composites (El-Sheikh, 2006).

\section{Preparation of ion exchangers No. VII}

Tow $g$ of dry orange peels were pre alkalized with $\mathrm{NaOH}$ as the procedure mentioned above they were refluxed in $40 \mathrm{ml}$ pyridine for one hour. A mixture of $2.5 \mathrm{ml}$ chlorosulfonic acid and $2.5 \mathrm{ml}$ of $\mathrm{POCl}_{3}$ were added with $10 \mathrm{ml}$ of 1,2-Dichloroethane then added gradually with stirring the mixture for two hours with reflux. The mixture was filtered and washed with dilute $\mathrm{HCl}(5 \% ; V / V)$ till no odors of pyridine. The mixture was washed with distilled water till no color with methyl orange. The prepared ion exchangers were dried giving No. VII. (cellulose-oxyphosphoric sulfonic acid composites) (El-Sheikh, 2006).

\section{Adsorption experimental procedure}

The prepared modified resins were packed over a suitable amount of glass wool in Pyrex columns (50 cm in height, and $1 \mathrm{~cm}$ in diameter) Adsorption experiments were conducted by passing synthetic solution of uranium adjusted at $\mathrm{pH} 4$ through the prepared resins from No 1 to VII ( $1 \mathrm{~g}$ was used of each resin), with a flow rate of $0.33 \mathrm{ml} / \mathrm{min}$. Periodical $10 \mathrm{ml}$ samples were collected through the adsorption steps until the representative resin was completely saturated (influent concentration $=$ effluent concentration). The same procedure was used applied with the modified orange peels from resin No 1 to VII to adsorb the uranium and associated metals form water in Alluga wells. This process accomplished by passing one liter of water sample through each wet settled resin of different modified resin (El-Sheikh, 2006)

\section{Uranium status in under groundwater}

The water sample was collected three times throughout of the year from wells in Alluga, Sinai. Water Sample was subjected to complete chemical analyses of cation and anion content to monitor the uranium status. The different stream solutions were subjected to the oxidimetric titration method against ammonium metavanadate was used after its reduction. The associated elements of uranium in water samples were analyzed as well as the mineral elements of orange peels using prism ICP-OES, Teledyne technologies (Inductively Coupled Plasma Optical Emission Spectrometer) Finally, the obtained resins from No. I to VII were also qualitatively analyzed using SEM-EDX analysis to confirm the uranium presence. 


\section{RESULTS AND DISCUSSION}

\section{Factors Affecting Uranium (U) Adsorption Efficiency}

There are different factors controlling uranium adsorption from their solutions. Some of these factors are related to the natural media such as particles size and type of natural resin, while others are related to the solution it self such as solution $\mathrm{pH}$, flow rate, contact time, and $\mathrm{U}$ concentration.

\section{Particles size}

The particle size of the ion exchanger mass affects the uranium adsorption efficiency. In the present study, the raw material of orange peels were ground and sieved to particle sizes range from $(0.841,0.400,0.250,0.149$ to 0.125$) \mathrm{mm}$. When passing a synthetic solution containing $200 \mathrm{mg} / \mathrm{l}$ uranium upon each size of the previously ground orange peels $(1 \mathrm{~g})$, the uranium adsorption efficiency was almost complete at (0.841:0.250) $\mathrm{mm}$ particle sizes (Fig. 1). Other particles gave less uranium adsorption efficiency.

\section{Effect of swelling on ion exchangers}

In order to measure the swelling factor affecting the untreated orange peels and modified orange peels as ion exchanger sample from No. I to VII, a constant volume of each ion exchanger is immersed in water. Volume change for each sample was evaluated. It was found that the phosphate ion exchanger No. (V) was higher than the other types (Table 3)

Swelling media reacts with the hydrogen and oxygen atoms of the cellulose during the cleavage of some hydrogen bonds and the opening pores were produced. Due to this penetration of water into the cellulosic material, the porosity of cellulose increases and this increases its reactivity.

\section{pH}

The effect of synthetic solution $\mathrm{pH}$ on uranium adsorption efficiency was studied in the $\mathrm{pH}$ range from 1 to 8 . Synthetic solution of 300 $\mathrm{mg} / \mathrm{l}$ uranium was used for this investigation based upon that the non-treated orange peels have the particles size $(0.841: 0.250) \mathrm{mm}$. We used the low concentration of uranium to avoid uranium precipitation at $\mathrm{pH}$ about 5 or more.
The maximum uranium adsorption efficiency (90\%) was achieved at $\mathrm{pH} 4-5$ as shown in Table 4. This phenomenon can be attributed to interaction between the surface charge of the adsorbent and the $\mathrm{H}^{+}$ions concentrations in the solution. At high $\mathrm{pH}$ values the surface of the adsorbent would have much higher negative charges; a matter which results higher attraction of the solution cations. The obtained results are actually in agreement with comparable results obtained for other biomass materials such as the orange waste (Dhakal et al., 2005), the sago waste (Quek et al., 1998) and the saw dust (Sciban et al., 2006; El-Sheikh, 2013).

\section{Flow- rate}

Passing synthetic uranium solution through the un-treated orange peels sample particle size (0.841:0.250) $\mathrm{mm}$, and flow rates of $0.33,0.5,1$, $2,3,4,5$ and $6 \mathrm{ml} / \mathrm{min}$. The obtained results indicated that, the uranium adsorption efficiency decreases from 80.11 to $50.3 \%$ by increasing the flow rate from 0.33 to $5 \mathrm{ml} / \mathrm{min}$. These results are in agreement with El-Sheikh et al. (2013). Therefore, the flow rate $0.33 \mathrm{ml} / \mathrm{min}$. was the superior for uranium adsorption investigations (Fig. 2).

\section{Adsorption capacity of the exchange resins}

Ion exchangers are solid materials characterized by high molecular weight insoluble compound polyelectrolytes. Ion exchangers can exchange their mobile ions for ions of equal charge from the surrounding medium. Thus, high molecular weight acids or base can exchange their hydrogen or hydroxyl ions for equal charged ions and can convert into high molecular salts of the ion exchanger. This process is known as cation exchange while the anionprocess takes place when the $\mathrm{OH}$ exchanger neutralizes with an acid and the anion which was previously bounded to the ion exchanger, can again be displaced by another anion. The most widely used modern ion exchangers are organic materials based on synthetic resins. The macromolecule of the ion exchanger in the most general case represents a three dimensional network with a large number of attached ionizable groups. Ion exchange processes require a mediating agent generally water, in which the exchanging ions are dissolved. 


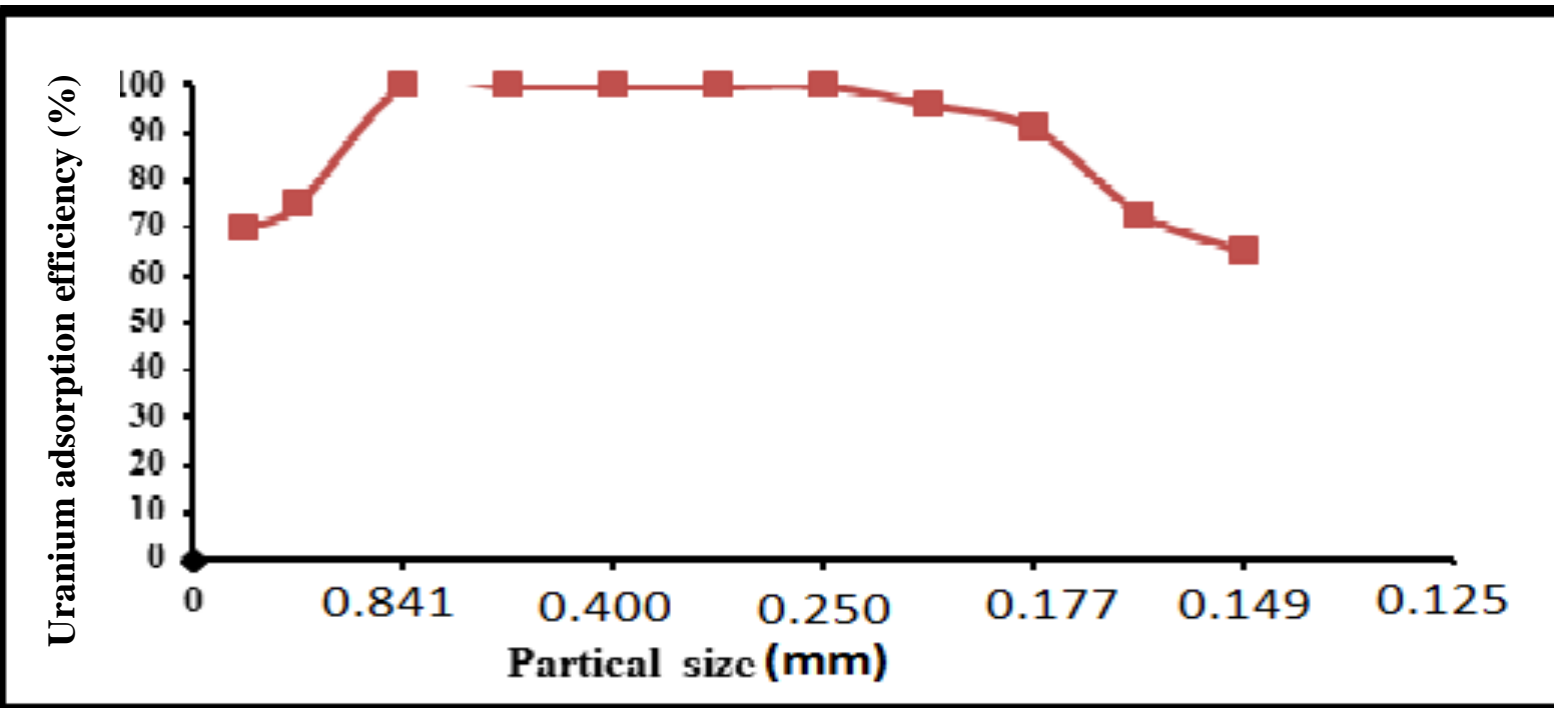

Fig. 1.Effect of particles size of orange peels on uranium adsorption efficiency from synthetic solution

Table 3. Swelling effect of the investigated ion exchangers

\begin{tabular}{lccc}
\hline Ion exchanger No. & Dry weight (g) & Wet settled resin (wsr) g & Swelling (\%) \\
\hline (1) & 2.5 & 2.6 & $4 \%$ \\
(II) & 2.5 & 2.9 & $16 \%$ \\
(III) & 2.5 & 2.8 & $12 \%$ \\
(IV) & 2.5 & 2.8 & $12 \%$ \\
(V) & 2.5 & 3.0 & $20 \%$ \\
(VI) & 2.5 & 2.9 & $16 \%$ \\
(VII) & 2.5 & 2.8 & $12 \%$ \\
\hline
\end{tabular}

Table 4. Effect of pH upon uranium adsorption efficiency

\begin{tabular}{lccc}
\hline $\mathbf{p H}$ & Adsorption efficiency (\%) & $\mathbf{p H}$ & Adsorption efficiency (\%) \\
\hline $\mathbf{1}$ & 60 & 5 & 90 \\
$\mathbf{2}$ & 74 & 6 & 87 \\
$\mathbf{3}$ & 86 & 7 & 85 \\
$\mathbf{4}$ & 90 & 8 & 80 \\
\hline
\end{tabular}




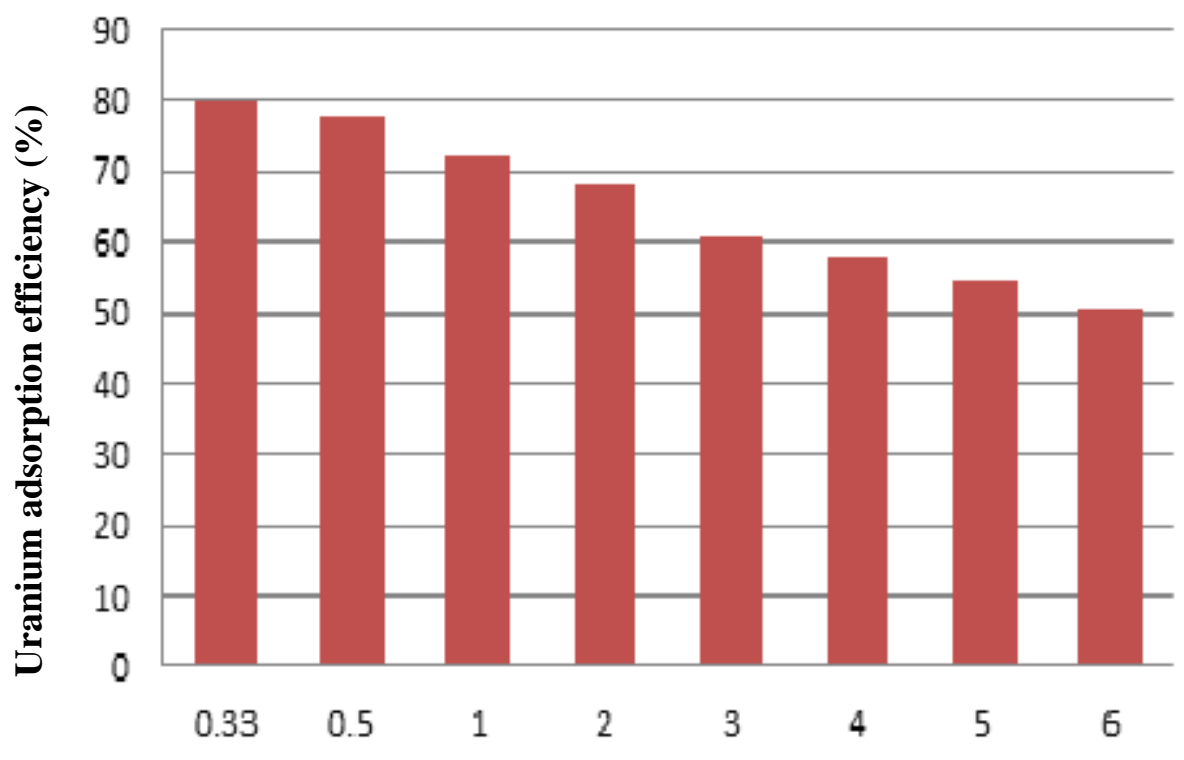

Flow rate, $\mathrm{ml} / \mathrm{min}$.

Fig. 2. Effect of flow- rate on uranium adsorption efficiency

\section{Adsorption capacity of resin No. 1}

One gram of wet settled resin of untreated orange peels with particles of (0.841: 0.250$) \mathrm{mm}$ size was conducted with synthetic uranium solution (1000) $\mathrm{mg} / \mathrm{l}$ under experimental optimum condition in column with flow rate of 0.33 $\mathrm{ml} / \mathrm{min}$. Saturation capacity of the untreated orange peel ion exchange reached $60 \mathrm{mg} / \mathrm{g}$ as shown in Table 5. To explain the reaction between the nature ion exchanger or cellulose ion exchanger, samples before treating with uranium solution and after treating one was subjected to Scanning Electron Microscope (SEM) analysis. It is clear that pores in the cellulose that's in orange peels surface are already present in nature and can also be generated during chemical and mechanical treatments (Park et al., 2006; El-Sheikh, 2013). The (SEM) analytical data of the native orange peels before treatment are presented in Fig. 3-a showing the absence of any radioactive elements (U) in its pores, These pores were filled with uranium after the treatment of the orange peels with the uranium solution (Fig. 3-b). On other hand, the element test analysis indicate that, C:O:N with the $39.89: 6.94: 0.8$.

\section{Adsorption capacity of resin No. II}

Natural cellulose has low ion exchange properties, due to the small number of carboxyl groups in its constitution. Incorporation of different functional groups can obtain numerous reaction products. In this work, modification of orange peels with sodium hydroxide has been carried out to increase the capacity of ion exchange, swelling properties of the products and decrease their lignin content.

One gram of wet settled resin (wsr) orange peels pre-treated with sodium hydroxide of (0.841:0.250) $\mathrm{mm}$ size was conducted with synthetic uranium solution (1000) $\mathrm{mg} / \mathrm{l}$ in column under experimental optimum condition, with flow rate of $0.33 \mathrm{ml} / \mathrm{min}$ Saturation capacity of (ion exchange No II) reached 244 $\mathrm{mg} / \mathrm{g}$ as shown in Table 6. To explain the reaction, samples before treating with uranium solution and after treating were subjected to Scanning Electron Microscope (SEM) analysis. 
Table 5. Uranium saturation capacity by the orange peels ion exchanger No. I

\begin{tabular}{ccc}
\hline $\begin{array}{c}\text { Contact number } \\
\mathbf{1 0 0 0} \mathbf{~} \mathbf{~ g / l} \text { in } \mathbf{1 0} \mathbf{~ m l}\end{array}$ & $\begin{array}{c}\text { Uranium adsorption } \\
\text { efficiency }(\boldsymbol{\%})\end{array}$ & $\begin{array}{c}\text { Loaded amount of uranium } \\
(\mathbf{m g} / \mathbf{1 g})\end{array}$ \\
\hline $1-4$ & 100 & 40 \\
5 & 64 & 6.4 \\
6 & 51 & 5.1 \\
7 & 42 & 4.2 \\
8 & 32 & 3.2 \\
9 & 8 & 0.8 \\
10 & 3 & Nil \\
Total & & $60 \mathrm{mg} /$ one g wsr No. I
\end{tabular}

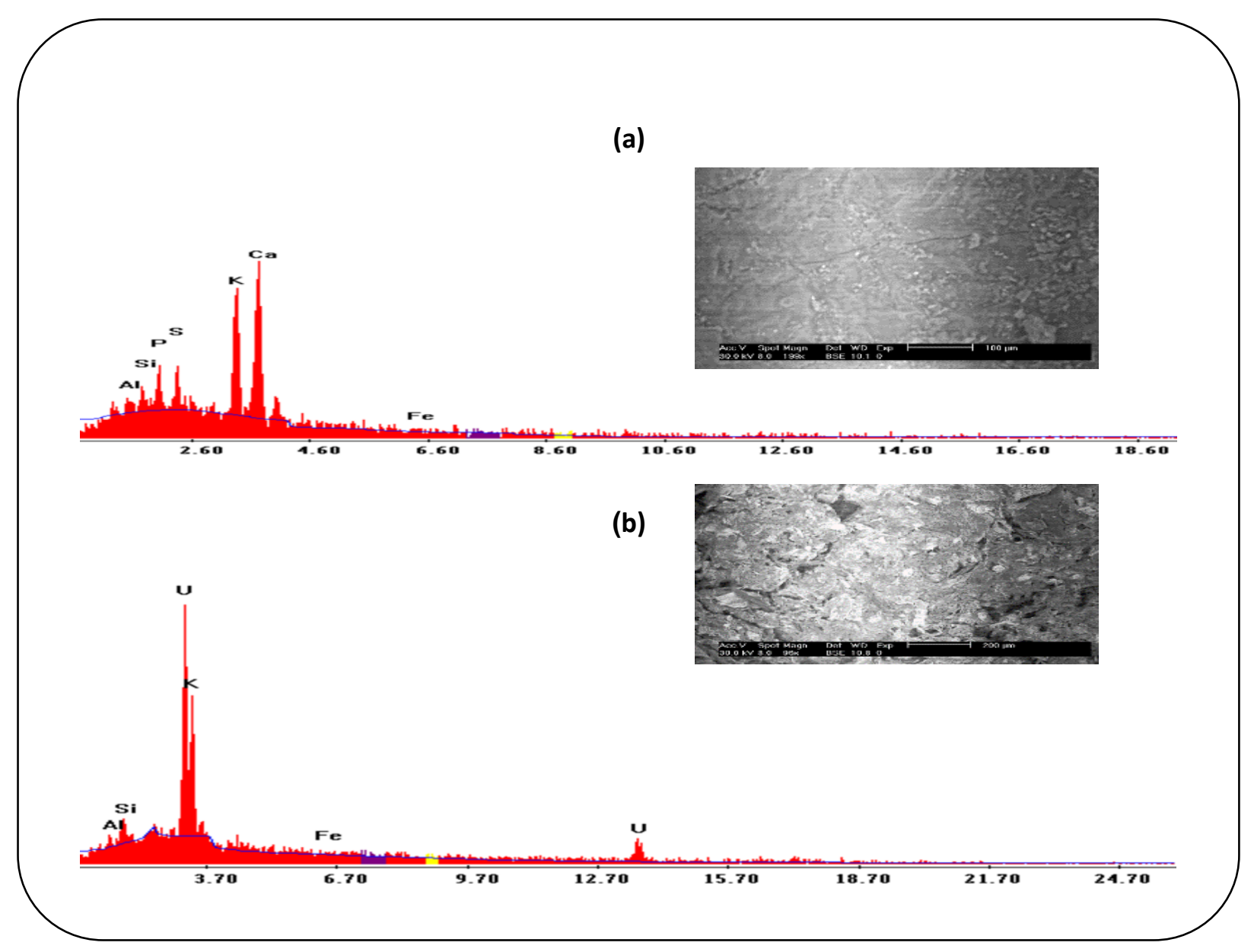

Fig. 3. Scanning Electron Microscope SEM spectrum and image for exchanger (No. I) orange peels before treatment (a) and after treatment (b) 
Table 6. Uranium saturation capacity of the ion exchanger No. II

\begin{tabular}{ccc}
\hline $\begin{array}{c}\text { Contact number } \\
\mathbf{1 0 0 0} \mathbf{~} \mathbf{~ g / l} \text { in } \mathbf{1 0} \mathbf{~ m l}\end{array}$ & $\begin{array}{c}\text { Uranium adsorption efficiency } \\
(\mathbf{\%})\end{array}$ & $\begin{array}{c}\text { Loaded amount of uranium } \\
(\mathbf{m g} / \mathbf{1 g})\end{array}$ \\
\hline $1-20$ & 100 & 220 \\
21 & 70 & 7 \\
22 & 61 & 6.1 \\
23 & 53 & 5.3 \\
24 & 25 & 2.5 \\
25 & 13 & 1.3 \\
26 & 9 & 0.9 \\
27 & 9 & 0.9 \\
Total & & $244 \mathrm{mg} /$ one g wsr No. II \\
\hline
\end{tabular}

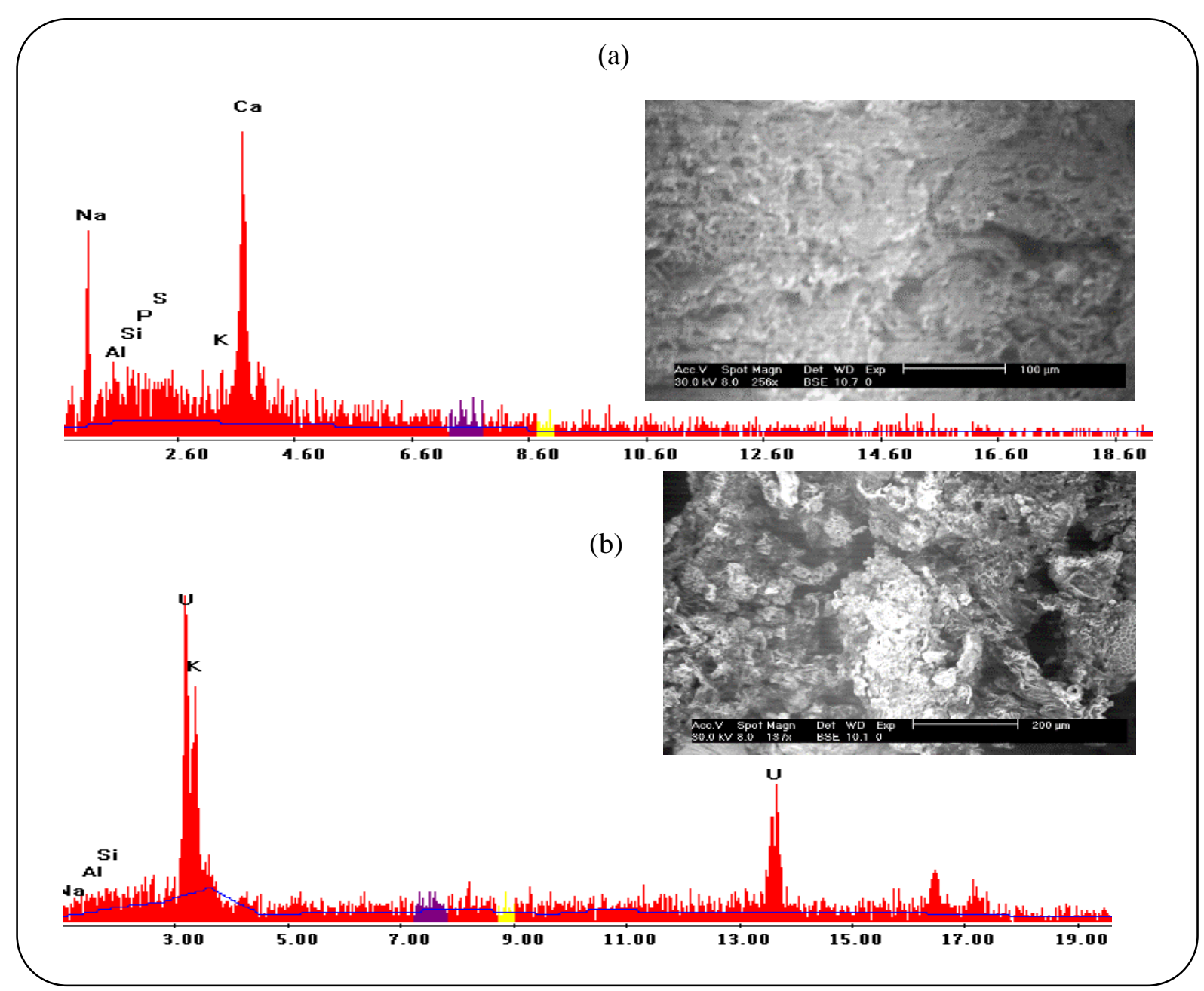

Fig. 4. Scanning Electron Microscope SEM spectrum and image of ion exchanger (No. II) before treatment (a) and after treatment (b) 
The (SEM) analytical results of the ion exchange No (II), i.e., before treatment presented in Fig. 4-a establish the absence of any radioactive elements (U). On the other hand, the (SEM) analytical results of the ion exchanger No. II reacted with uranium solution indicate the presences of uranium element, as presented in Fig. 4-b. The element test analysis indicate that, C:O:N with the $39.89: 6.94: 0.8$.

The reaction between methyl esters can be modified to carboxylate ligands by treating the biomass with a base such as sodium hydroxide, thereby increasing the metal-binding ability of the biomass. The hydrolysis reaction of the methyl esters is as follows:

\section{$\mathrm{R}-\mathrm{COOCH} 3+\mathrm{NaOH} \mathrm{R}-\mathrm{COO}^{-} \rightarrow+\mathrm{CH} 3 \mathrm{OH}+\mathrm{Na}^{+}$}

Therefore, chemically modifying the biomass increases the number of carboxylate ligands, which can enhance the binding ability of the biomass (Feng et al., 2009).

\section{Adsorption capacity of resin (ion exchanger} No. III)

One gram of Wet settled resin (wsr) of orange peels pre-treated with sodium hydroxide of $(0.841: 0.250) \mathrm{mm}$ size was modified using tri-ethyl amine and epichorohydrine. The prepared ion exchanger No. III were conducted in column with synthetic uranium solution (1000 $\mathrm{mg} / \mathrm{l})$ under experimental optimum condition, with flow rate of $0.33 \mathrm{ml} / \mathrm{min}$.

Saturation capacity of one gram wsr (ion exchange No III) reached $91 \mathrm{mg} / \mathrm{g}$ as it shown in Table 7 . The low capacity of the ion exchanger No (III) may be attributed to the steric effect. To explain the reaction between the nature ion exchanger No III, samples before treating with uranium solution and after treating subjected to Scanning Electron Microscope (SEM) analysis. The results indicated, The (SEM) analytical results of the ion exchange No. (III) i.e., before treatment (Fig. 5-a) establish the absence of any radioactive elements (U) on the other hand, (SEM) analytical results of the treated orange peels (ion exchanger No. III) reacted with uranium solution indicating the presence of uranium elements (Fig. 5-b). On other hand, the elements test analysis indicate that, $\mathrm{C}: \mathrm{O}: \mathrm{N}$ with the $32.89: 8.33: 4.23$.

\section{Adsorption capacity of resin ion exchanger No IV}

One gram of Wet settled resin (wsr) orange peels with (0.841:0.250) mm size was modified using tri-ethyl amine and epichorohydrine according to the experimental equation in ion exchanger no III. The prepared ion exchanger No. IV was conducted in column, with synthetic uranium solution $(1000 \mathrm{mg} / \mathrm{l})$ under mentioned optimum condition with flow rate of $0.33 \mathrm{ml} /$ $\min$.

Saturation capacity of the wsr modified orange peel (ion exchange No. IV) reached $109.9 \mathrm{mg} / \mathrm{g}$ as shown in Table 8. The low capacity of the ion exchanger No (IV) may be attributed to the steric effect, for this reason there is no noticeable difference between both ion exchanger No. (III and IV). To explain the reaction between the ion exchanger No. IV, samples before treating with uranium solution and after treating subjected to Scanning Electron Microscope (SEM) analysis. The (SEM) analytical results of the ion exchange No. (IV) are shown in Fig. 6-a proving the absence of any radioactive elements (U). The (SEM) analytical results of ion exchanger No. IV reacted with uranium solution indicating the presence of uranium element (Fig. 6-b). On other hand, the element test analysis indicate that, $\mathrm{C}: \mathrm{O}: \mathrm{N}$ with the $37.51: 10.59: 6.59$.

\section{Adsorption capacity of resin ion exchanger No. V}

One gram of wet settled resin orange peels with (0.841:0.250) mm size was modified using phosphorus oxychloride in alkaline medium according to the following equation which reported by Horrocks and Zhang (2001) , as a result of esterfication of the hydroxyl groups increase the adsorption

\section{Cell-OH+POCl+ Pyridine $\rightarrow$ Cell-O- $\mathrm{POCl}_{2}+$ Pyridine. $\mathrm{HCl}$}

The prepared ion exchanger No. V was conducted in column with synthetic uranium solution $(1000 \mathrm{mg} / \mathrm{l})$ under experimental optimum condition, with flow rate $0.33 \mathrm{ml} / \mathrm{min}$. 
Table 7. Uranium saturation capacity of the ion exchanger No (III)

\begin{tabular}{ccc}
\hline $\begin{array}{c}\text { Contact number } \\
\mathbf{1 0 0 0} \mathbf{~} \mathbf{~ g / l} \text { in } \mathbf{1 0} \mathbf{~ m l}\end{array}$ & $\begin{array}{c}\text { Uranium adsorption efficiency } \\
(\boldsymbol{\%})\end{array}$ & $\begin{array}{c}\text { Loaded amount of uranium } \\
(\mathbf{m g} / \mathbf{1 g})\end{array}$ \\
\hline $1-7$ & 100 & 70 \\
8 & 71 & 7.1 \\
9 & 65 & 6.5 \\
10 & 3. & 3.8 \\
11 & 26 & 2.6 \\
12 & 11 & 1.1 \\
Total & & $91.1 \mathrm{mg} /$ one g wsr No. III \\
\hline
\end{tabular}

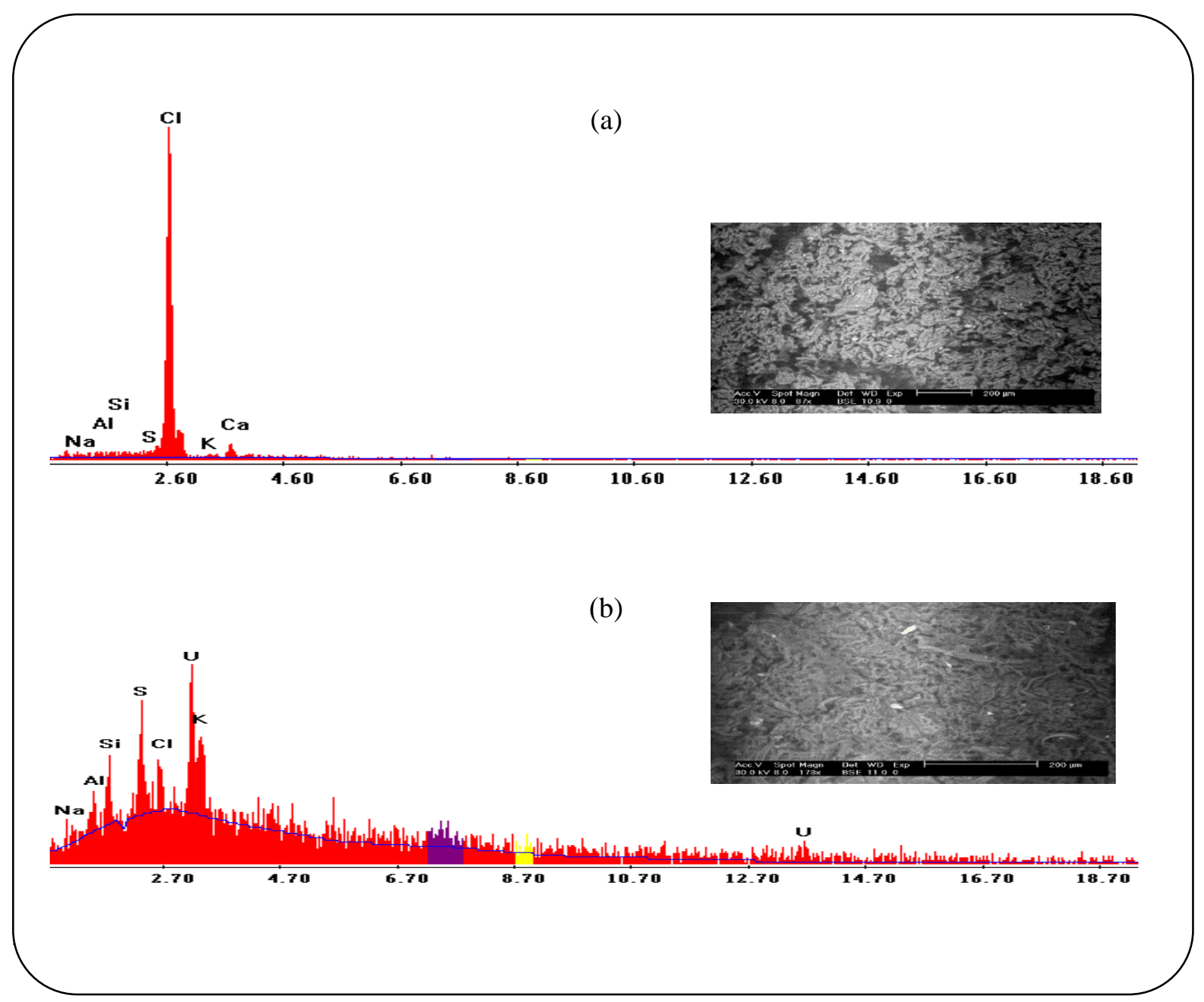

Fig. 5. Scanning Electron Microscope SEM spectrum and image for exchanger (No. III) before treatment (a) and after treatment (b) 
Table 8. Uranium saturation capacity of the ion exchanger No (IV)

\begin{tabular}{ccc}
\hline $\begin{array}{c}\text { Contact number } \\
\mathbf{1 0 0 0} \mathbf{~} \mathbf{~ g / l} \text { in } \mathbf{1 0} \mathbf{~ m l}\end{array}$ & $\begin{array}{c}\text { Uranium adsorption efficiency } \\
(\mathbf{\%})\end{array}$ & $\begin{array}{c}\text { Loaded amount of uranium } \\
(\mathbf{m g} / \mathbf{1 g})\end{array}$ \\
\hline $1-9$ & 100 & 90 \\
21 & 70 & 7.0 \\
22 & 58 & 5.8 \\
23 & 43 & 4.3 \\
24 & 28 & 2.8 \\
Total & & $109.9 \mathrm{mg} /$ one g wsr No. IV \\
\hline
\end{tabular}

(a)

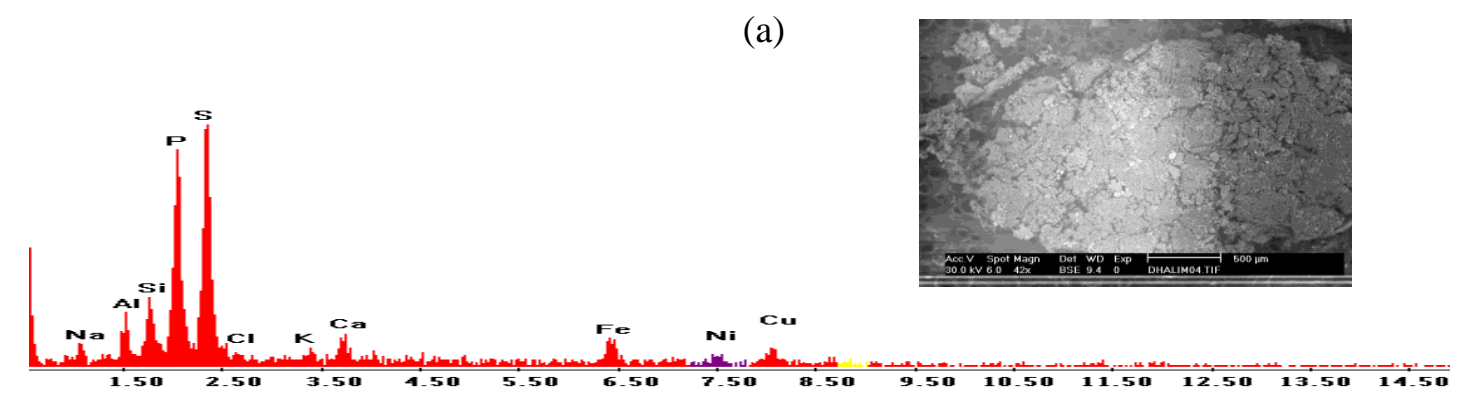

(b)

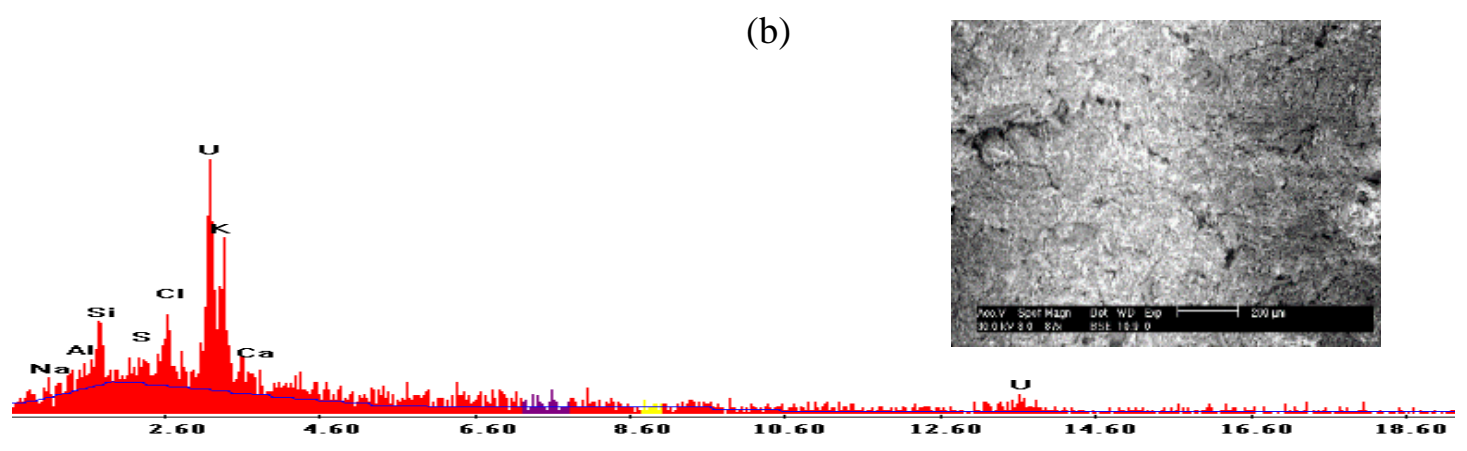

Fig. 6. Scanning Electron Microscope (SEM) spectrum and image for exchanger No. (IV) orange peels before treatment (a) and after treatment (b) 
Saturation capacity of the modified orange peel (ion exchange No. V) reached $431 \mathrm{mgU} / \mathrm{g}$ as shown in Table 9. The high capacity of the ion exchanger No. (V) may be attributed to the affinity of phosphate group to the uranium such as phosphein in DEPAH and TOPO. To explain the reaction between the ion exchanger No V, samples before treating uranium solution and after treating subjected to Scanning Electron Microscope (SEM) analysis. The (SEM) analytical results of the ion exchange No. (V) are shown in Fig. 7-a proving the absence of any radioactive elements (U). The (SEM) analytical results of the ion exchanger No. $\mathrm{V}$ reacted with uranium solution indicate the presences of uranium elements (Fig. 7-b). The element test analysis indicate that, C:O: P with the 27.85 : 5.56:7.27.

\section{Adsorption capacity of resin ion exchanger No VI}

One gram of Wet settled resin orange peels with 0.841:0.250 $\mathrm{mm}$ size was modified using chlorosulfonic acid, the mechanism was suggested as the following equation according to Hello et al. (2014). Thus, as a result of esterification of the hydroxyl groups increase the adsorption according to the following equation:

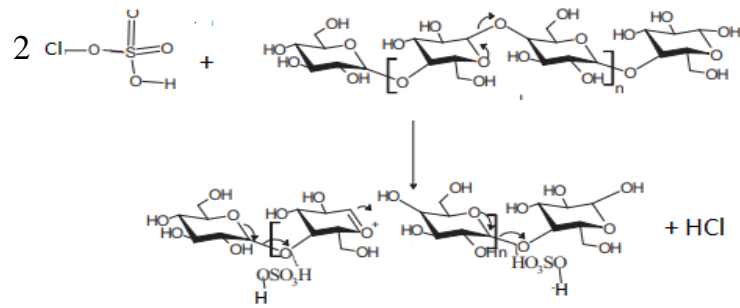

The prepared ion exchanger No. VI was conducted in column, with synthetic uranium solution (1000) $\mathrm{mg} / \mathrm{l}$ under experimental optimum condition with flow rate $0.33 . \mathrm{ml} / \mathrm{min}$.

Saturation capacity of the modified orange peel (ion exchange No. VI) reached $538 \mathrm{mg}$ $\mathrm{U} / \mathrm{g}$ as shown in Table 10. The high capacity of the ion exchanger No. (VI) may be attributed to increase of porosity is due to the rapture of the bond between lignin, cellulose and hemicellulose, which increases the free $\mathrm{OH}$ groups, and the efficiency towards sulfonation and formation of C-O-S bond.

To explain the reaction between the ion exchanger No. VI, samples before treating with uranium solution and after treating subjected to
Scanning Electron Microscope (SEM) analysis. From the latter, The (SEM) analytical results of the ion exchange no (VI) are shown in Fig. 8-a proven the absence of any radioactive elements (U). The (SEM) analytical results of (ion exchanger No. VI) reacted with uranium solution indicate the presences of uranium elements (Fig. 8-b). On other hand, the element test analysis indicate that, C:O:S with the $30.54: 6.06: 8.31$.

\section{Modification of orange peels by ion exchanger No. VII}

One gram of wet settled resin orange peels of 0.841: $0.250 \mathrm{~mm}$ size was modified using mixture chlorosulfonic acid and phosphorus oxychloride. Thus, as a result of esterfication of the hydroxyl groups increase the adsorption the prepared ion exchanger No. VII was conducted in column with synthetic uranium solution (1000) $\mathrm{mg} / \mathrm{l}$ under experimental optimum condition, with flow rate of $0.33 \mathrm{ml} / \mathrm{min}$. Saturation capacity of (ion exchange No. VII) reached $726 \mathrm{mg} \mathrm{U} / \mathrm{g}$ as shown in Table (11) The high capacity of the ion exchanger No. (VII) May be attributed to increase of porosity is due to the rapture of the bond between lignin, cellulose and hemicellulose, which increases the free $\mathrm{OH}$ groups, and the efficiency towards sulfonation and formation of $\mathrm{C}-\mathrm{O}-\mathrm{S}$ and C-O-P bond. To explain the reaction between the nature ion exchanger No. VII, samples before treating with uranium solution and after treating subjected to Scanning Electron Microscope (SEM) analysis. From the latter, the (SEM) analytical results of the ion exchange No (VII) i.e., before treatment are shown in Fig. 9-a proving the absence of any radioactive elements (U). The (SEM) analytical results of ion exchanger No. VII) reacted with uranium solution indicate the presences of uranium elements (Fig. 9-b). On other hand, the element test analysis indicate that, C:O:P:S with the 26.01 :3.82:5.18:6.24.

\section{Characterization of underground water sample (Water quality)}

\section{pH measurement}

The $\mathrm{pH}$ value of the investigated water sample ranges between 7.5 and 7.4 for water sample No 1 and water sample No. 2 respectively. Table 2 which this indicate slightly alkaline medium. The measurement of $\mathrm{pH}$ is an important factor to determine whether certain minerals precipitate or not. 
Table 9. Uranium saturation capacity of the ion exchanger NO (V)

\begin{tabular}{ccc}
\hline $\begin{array}{c}\text { Contact number } \\
\mathbf{1 0 0 0} \mathbf{~} \mathbf{~ g / l} \text { in } \mathbf{1 0} \mathbf{~ m l}\end{array}$ & $\begin{array}{c}\text { Uranium adsorption efficiency } \\
(\mathbf{\%})\end{array}$ & $\begin{array}{c}\text { Loaded amount of uranium } \\
(\mathbf{m g} / \mathbf{1 g})\end{array}$ \\
\hline $1-41$ & 100 & 410 \\
42 & 66 & 6.6 \\
43 & 52 & 5.2 \\
44 & 40 & 4.0 \\
45 & 31 & 3.1 \\
46 & 22 & 2.2 \\
Total & & $431 \mathrm{mg} /$ one g wsr No. V \\
\hline
\end{tabular}

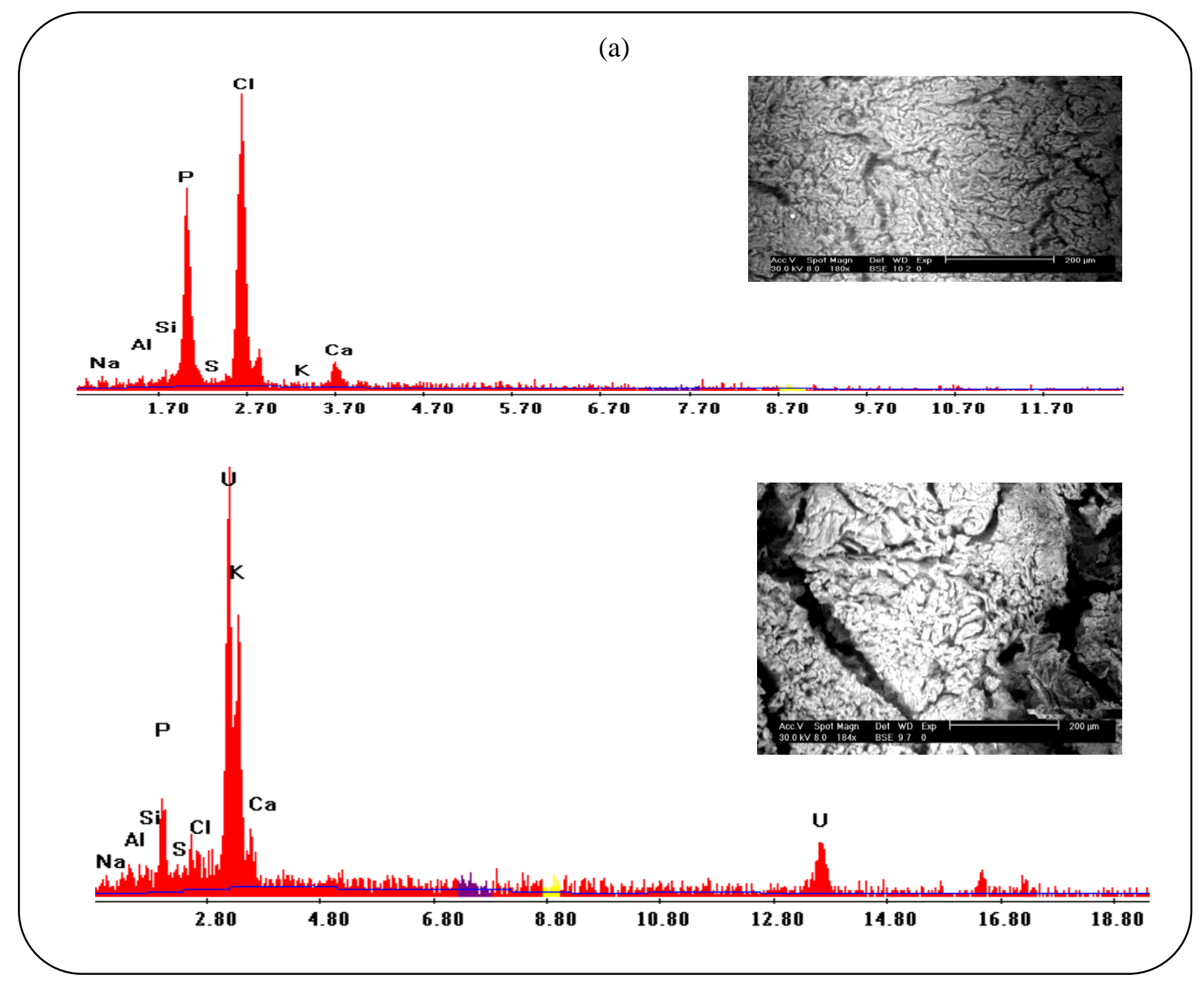

Fig. 7. Scanning Electron Microscope (SEM) spectrum and image for exchanger No. (V) before treatment (a) and after treatment (b) 
Table 10. Uranium saturation capacity of the ion exchanger No. (VI)

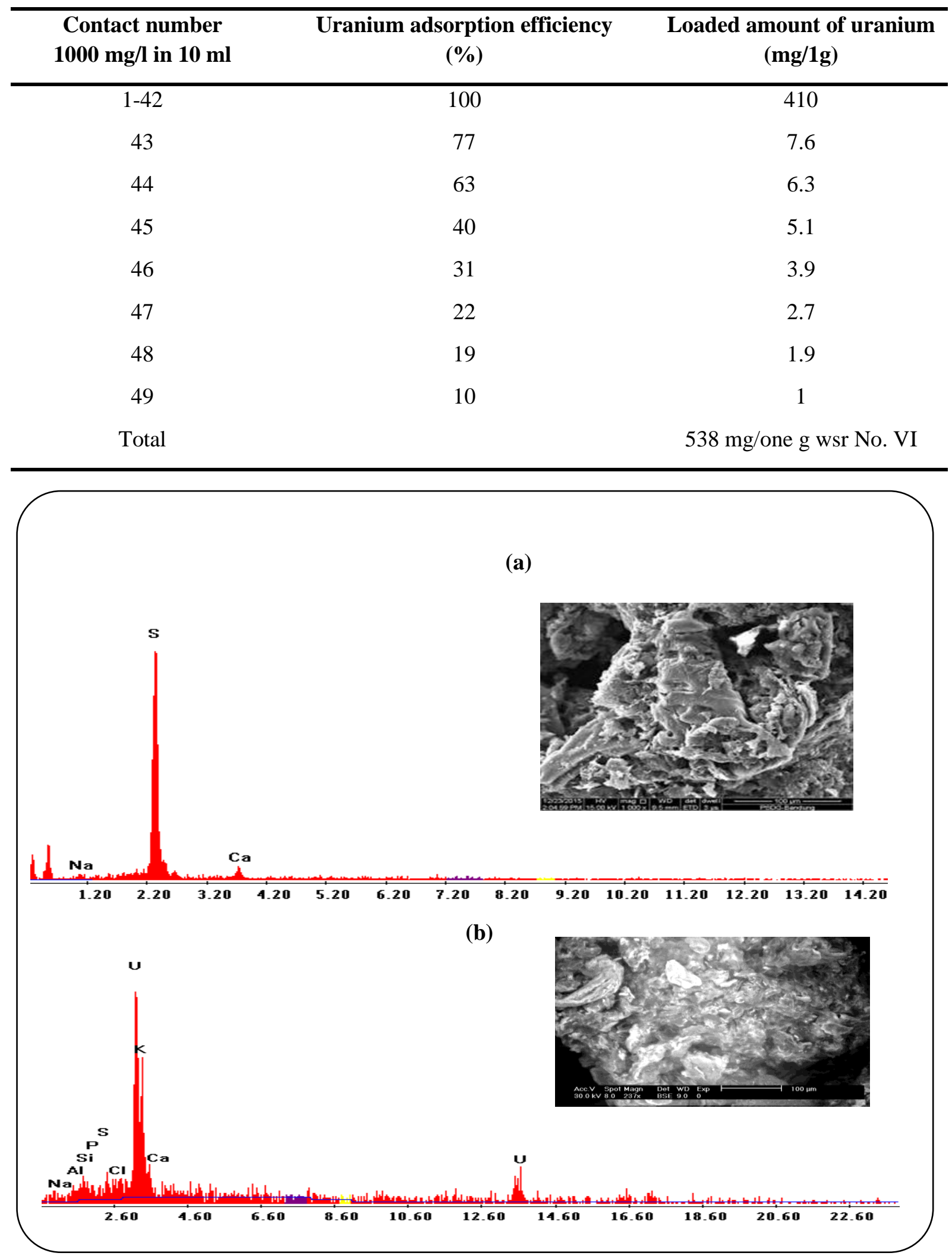

Fig. 8. Scanning Electron Microscope (SEM) spectrum and image for exchanger No (VI) orange peels before treatment (a) and after treatment (b) 
Table 11. Uranium saturation capacity of the ion exchanger No. (VII)

\begin{tabular}{ccc}
\hline $\begin{array}{c}\text { Contact number } \\
\mathbf{1 0 0 0} \mathbf{~} \mathbf{~} \mathbf{l} \text { in } \mathbf{1 0} \mathbf{~ m l}\end{array}$ & $\begin{array}{c}\text { Uranium adsorption efficiency } \\
(\mathbf{\%})\end{array}$ & $\begin{array}{c}\text { Loaded amount of uranium } \\
(\mathbf{m g} / \mathbf{1 g})\end{array}$ \\
\hline $1-70$ & 100 & 700 \\
71 & 73 & 7.3 \\
72 & 68 & 6.8 \\
73 & 55 & 5.5 \\
74 & 43 & 4.3 \\
75 & 11 & 1.1 \\
76 & 8 & 0.9 \\
77 & 2 & 0.2 \\
78 & 2 & 0.2 \\
Total & & $726 \mathrm{mg} / \mathrm{g}$ wsr No. VII \\
\hline
\end{tabular}

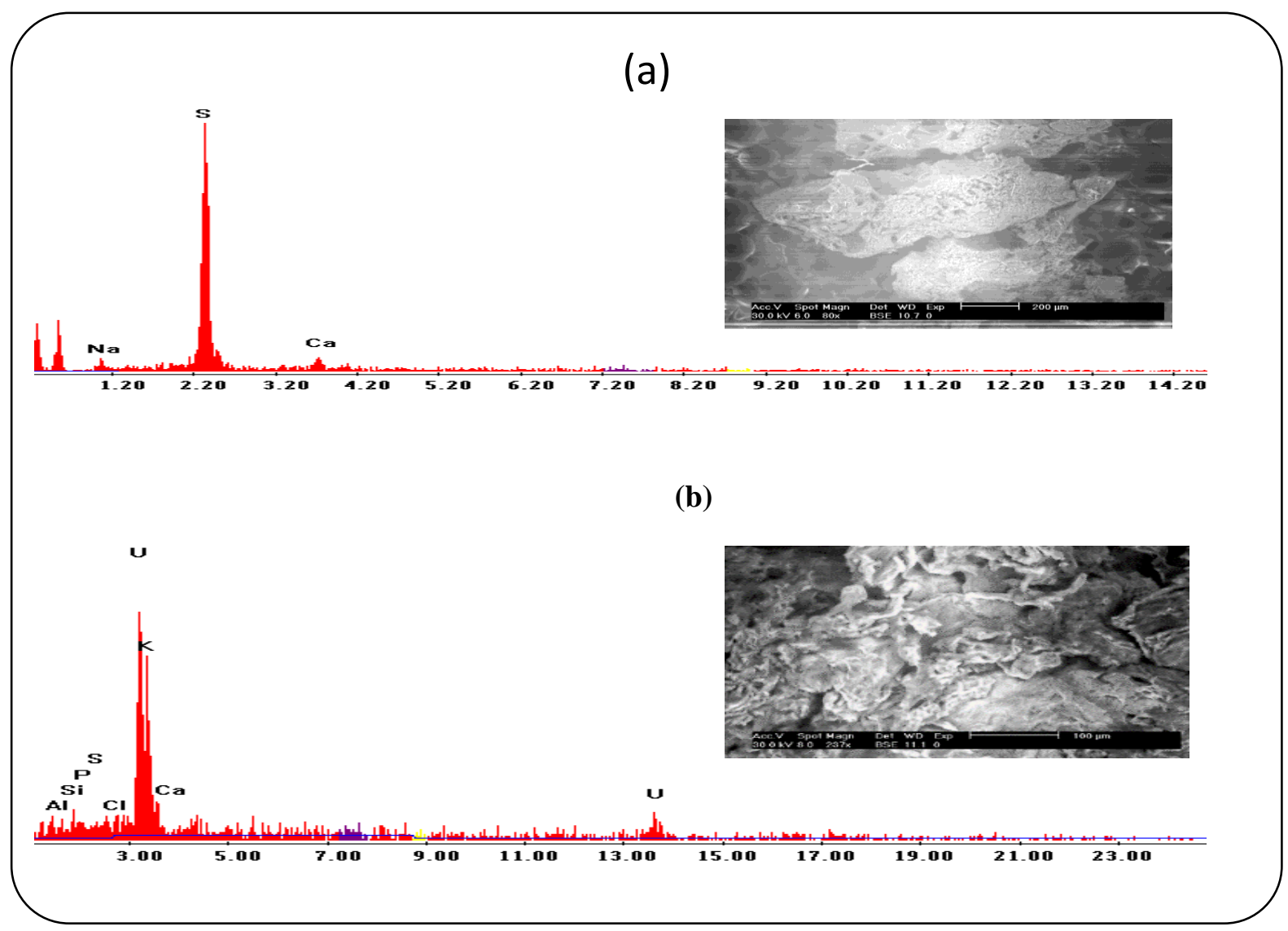

Fig. 9. Scanning Electron Microscope (SEM) spectrum and image for exchanger No. (VII) orange peels before treatment (a) and after treatment (b) 


\section{Total dissolved solid (TDS)}

High total dissolved solids may affect the aesthetic quality of the water, interfere with washing clothes and corroding plumbing fixtures. For aesthetic reasons, a limit of 500 $\mathrm{mg} / \mathrm{l}$ has been established as part of the Secondary Drinking Water Standards. Results were presented in Table 12 which was $887 \mathrm{mg} / \mathrm{l}$ (sample 1) and $1310 \mathrm{mg} / \mathrm{l}$ (sample 2). The variations are attributed to the lithology of the water bearing rocks

\section{Hydrochemical characteristics}

The hydrochemical characteristics of underground water samples are expressed as hydrochemical percentages and ion ratios. They are arranged in a decreasing order of their concentrations. Among the cationic concentrations, sodium is the most dominantion followed by calcium and magnesium ions $\left(\mathrm{Na}^{+}>\right.$ $\mathrm{Ca}^{2+}>\mathrm{Mg}^{2+}$ ). The chloride concentrations are the most dominant anions followed by sulphates and bicarbonates $\left(\mathrm{CI}^{-}>\mathrm{SO}_{4}^{-}>\mathrm{HCO}_{3}^{-}\right)$, this may be due to the presence of sandy dolostonelenses (Custodio and Bruggman, 1987).

\section{Evaluation for drinking water}

Depending on Chebotarov classification of ground water (Morsy, 2003), it is cleared that a classification for ground water based on its salinity (Table 12). It is found that water from wells No. 1and No.2 is fairly freshwater type with TDS ranges between 884 and 1310. (mg/l). Depending on the permissible limited of cations and anions in drinking water of ECAFE and UNESCO (1963) it can be defined that water are suitable for drinking purpose as shown in Tables 12 and 13.

\section{Applying the modified ion exchanger with the two tested water samples}

Trace elements have special interest and considerable importance in the study of the groundwater pollution. Trace elements found in water are a mirror of that found in the surrounded rocks which are leached by the movement of water and also controlled by the mineralogical changes which take place during alteration and nature of fluid. The concentration of the analyzed trace elements of the studied water wells are presented in Table 15, and compared to the maximum permissible concentrations in drinking and irrigation purposes. The maximum permissible limits for trace metals concentration of these elements were detected for drinking and irrigation water by the different organizations (WHO, 1984; FAO, 1985; EHCW, 1995).

Arsenic (As) is a natural element found widely in the earth's crust. It may be found in some drinking water supplies, including wells water. Exposure to high levels of arsenic can cause health effects. For most Canadians, the primary source of exposure to arsenic is food, followed by drinking water, soil and air. Health Canada and the International Agency for Research on Cancer consider arsenic a human cancer-causing agent that can increase the risk of cancer in internal organs such as the bladder, liver and lungs. After contact two water well samples with different ion exchanger, the water become sutible for drinking (Table 15). This is due to adsorbed of the excess of heavy metal specially arsenic. It is important to mention herein that the using orange peels without any modification could convert the wells water in to Permissible limits for drinking.

The zinc ( $\mathrm{Zn})$ plays an essential role in human metabolism, The total content of $\mathrm{Zn}$ in the earth's crust is $200 \mathrm{mg} / \mathrm{l}$ by weight. The guideline value of $\mathrm{Zn}$ permissible in drinking water is $3000 \mu \mathrm{g} / \mathrm{l}(\mathbf{W H O}, \mathbf{1 9 9 3})$. For irrigation water, the permissible limits ranging between 2000 and $10000 \mu \mathrm{g} / \mathrm{l}$ (WHO, 1984). The concentration of $\mathrm{Zn}$ in the water well (No. 1) was $65 \mu \mathrm{g} / 1$ and $43 \mu \mathrm{g} / 1$ in well (No.2). Accordingly, all water wells have values lower than the permissible values for both drinking and irrigation purposes.

The lead $(\mathrm{Pb})$ is belonging to the most dangerous heavy metal pollutants in surface water which represents an exchangeable ion for calcium and potassium. The increase in $\mathrm{Pb}$ content in water is due to leaching of lead bearing minerals as a result of weathering. The recommended guideline value for drinking water is $50 \mu \mathrm{g} / 1$ (EPA, 2002), while the maximum concentration level is $10 \mu \mathrm{g} / \mathrm{l}$ (WHO, 1993). The maximum recommended concentration of lead in irrigation water is $5000 \mu \mathrm{g} / \mathrm{l}$ (FAO, 1985). Date in Tables 15 and 16 indicate that 
Table 12. Classification of ground water according to Chebotarov (1955) and (Morsy, 2003)

\begin{tabular}{lllll}
\hline & \multicolumn{3}{c}{ Chebotarov classification of groundwater } \\
\hline TDS $(\mathbf{m g} / \mathbf{l})$ & Unit & Type & Quality & Well No. \\
\hline $\mathbf{5 0 0}$ & $\mathrm{mg} / \mathrm{l}$ & Fresh water & Good potable & \\
$\mathbf{5 0 0 - 7 0 0}$ & $\mathrm{mg} / \mathrm{l}$ & & Fresh & 1 and 2 \\
$\mathbf{7 0 0 - 1 5 0 0}$ & $\mathrm{mg} / \mathrm{l}$ & & Fairly fresh & \\
$\mathbf{1 5 0 0 - 2 0 0 0}$ & $\mathrm{mg} / \mathrm{l}$ & & Possible fresh & \\
$\mathbf{3 2 0 0 - 4 0 0 0}$ & $\mathrm{mg} / \mathrm{l}$ & Brackish water & Slightly Brackish & \\
$\mathbf{4 0 0 0 - 5 0 0 0}$ & $\mathrm{mg} / \mathrm{l}$ & & Definitely Brackish & \\
$\mathbf{5 0 0 0 - 6 0 0 0}$ & $\mathrm{mg} / \mathrm{l}$ & & & \\
$\mathbf{6 0 0 0 - 7 0 0 0}$ & $\mathrm{mg} / \mathrm{l}$ & Saline water & Slightly salty & \\
$\mathbf{7 0 0 0 - 1 0 0 0 0}$ & $\mathrm{mg} / \mathrm{l}$ & & & \\
\hline
\end{tabular}

Table 13. ECAFE and UNESCO (1963) permissible limited of cations and anions in drinking water

\begin{tabular}{ccc}
\hline Substance & Permissible (mg/l) & Excessive (mg/l) \\
\hline TDS & 500 & 1500 \\
$\mathbf{C a}^{++}$ & 75 & 200 \\
$\mathbf{M g}^{++}$ & 50 & 150 \\
$\mathbf{S O}^{--}$ & 200 & 400 \\
$\mathbf{C l}^{-}$ & 200 & 600 \\
$\mathbf{p H}$ range & $6.5-7.5$ & \\
\hline
\end{tabular}

Table 14. Effect of resin on adsorption of uranium and associated heavy elements of Alluga well water No. 1

\begin{tabular}{|c|c|c|c|c|c|c|c|}
\hline \multicolumn{8}{|c|}{ Well No. 1} \\
\hline Metals before treatment $(\mathrm{Mg} / \mathrm{l})$ & As & $\mathbf{Z n}$ & $\mathbf{p b}$ & $\mathbf{C d}$ & Mn & $\mathbf{C u}$ & $\overline{\mathbf{U}}$ \\
\hline Resin name & 68 & 65 & 37 & 42 & 22 & 40 & 120 \\
\hline \multicolumn{8}{|c|}{ After treating with modified ion exchanger $(\mu \mathrm{g} / \mathrm{l})$} \\
\hline Ion exchanger No 1 & 53 & 26 & 3 & 3 & 1 & 3 & nil \\
\hline Ion exchanger No II & 1 & 14 & nil & 2 & nil & 1 & nil \\
\hline Ion exchanger No III & 16 & 22 & 1 & 2 & nil & 2 & nil \\
\hline Ion exchanger No IV & 29 & 21 & 3 & 2 & 1 & 1 & nil \\
\hline Ion exchanger No $\mathrm{V}$ & 15 & 10 & nil & 1 & nil & nil & nil \\
\hline Ion exchanger No VI & 10 & 15 & 2 & 1 & nil & nil & nil \\
\hline Ion exchanger No VII & 15 & 17 & 2 & nil & nil & nil & nil \\
\hline
\end{tabular}


Table 15. Effect of resin on adsorption uranium and associated heavy elements of Alluga well water No. 2

\begin{tabular}{|c|c|c|c|c|c|c|c|}
\hline \multicolumn{8}{|c|}{ Well No. 2} \\
\hline Metals before treatment $(\mathrm{Mg} / \mathrm{l})$ & $\overline{\mathbf{A S}}$ & $\mathbf{Z n}$ & $\mathbf{P b}$ & $\overline{C d}$ & Mn & $\mathbf{C u}$ & $\mathbf{U}$ \\
\hline Resin name & 81 & 43 & 92 & 33 & 45 & 52 & 70 \\
\hline \multicolumn{8}{|c|}{ After treating with modified ion exchanger $\mu \mathrm{g} / \mathrm{L}$} \\
\hline Ion exchanger No. 1 & 45 & 6 & 4 & 2 & 3 & 3 & nil \\
\hline Ion exchanger No II & 1 & nil & 3 & nil & 2 & 1 & nil \\
\hline Ion exchanger No III & 11 & 1 & 5 & 2 & 3 & 2 & nil \\
\hline Ion exchanger No IV & 25 & 3 & 5 & 1 & 3 & 3 & nil \\
\hline Ion exchanger No $\mathrm{V}$ & 29 & nil & nil & nil & nil & 1 & nil \\
\hline Ion exchanger No VI & 10 & nil & 3 & nil & nil & nil & nil \\
\hline Ion exchanger NoVII & 16 & 1 & 3 & nil & nil & 1 & nil \\
\hline
\end{tabular}

Table 16. Permissible limits of heavy metal for drinking ( $\mu \mathrm{g} / \mathrm{l})$

\begin{tabular}{|c|c|c|c|c|c|c|c|}
\hline \multicolumn{8}{|c|}{ Permissible limits for drinking, $\mu \mathrm{g} / \mathrm{L}$} \\
\hline REFERENCES & As & $\mathbf{Z n}$ & $\mathbf{P b}$ & $\mathbf{C d}$ & Mn & $\mathbf{C u}$ & $\mathbf{U}$ \\
\hline WHO 1984 & & & & & $100-500$ & 1000 & 120 \\
\hline WHO 1993 & 50 & 3000 & 10 & & & & \\
\hline EPA2002 & & 5000 & 50 & 3 & & & 9 \\
\hline \multicolumn{8}{|c|}{ Permissible limits for irrigation $(\mu \mathrm{g} / \mathrm{l})$} \\
\hline WHO 1984 & & $2000-100$ & & & & & \\
\hline FAO1985 & & & 500 & & 200 & 2000 & \\
\hline
\end{tabular}

lead content in water wells is much lower than this recommended guideline value. The concentration of $\mathrm{Pb}$ in the studied water well (No. 1) is $37 \mu \mathrm{g} / 1$ and in the well water (No. 2) $92 \mu \mathrm{g} / \mathrm{l}$.

The cadmium $(\mathrm{Cd})$ is a relative rare metal, and considered as one of the most toxic metals pollutants in surface water. Chemically $\mathrm{Cd}$ is very similar to zinc and both metals frequently undergo geochemical processes together. The permissible value of $\mathrm{Cd}$ for drinking water is 3 $\mu \mathrm{g} / \mathrm{l}$ (WHO, 1993), while the permissible limits of $\mathrm{Cd}$ for drinking water does not exceed $5 \mu \mathrm{g} / \mathrm{L}$ (EPA, 2002) Cadmium concentration in the well Water (No. 1) was $42 \mu \mathrm{g} / 1$ and in the well Water (No. 2) was $33 \mu \mathrm{g} / 1$.

The manganese $(\mathrm{Mn})$ is an essential element for both plants and animals' life forms. The guideline value for $\mathrm{Mn}$ in drinking water is 100$500 \mu \mathrm{g} / 1$ (WHO, 1984). Manganese content in 
the studied water wells ranging between $22 \mu \mathrm{g} / 1$ in well purposes (No.1) and $45 \mu \mathrm{g} / 1$ in well (No.2). Therefore, all water wells are suitable for drinking and irrigation. The maximum recommended concentration of $\mathrm{Mn}$ is $200 \mu \mathrm{g} / \mathrm{l}$ (FAO, 1985) therefore all studied water wells are suitable for irrigation.

Copper $(\mathrm{Cu})$ Soluble copper compounds form the largest threat to human health. Continuous inhalation of copper-containing spray cause lung cancer among exposed workers. Copper can be found in many kinds of food, in drinking water and in air. Because of that we absorb eminent quantities of copper each day by eating, drinking and breathing. The absorption of copper is necessary, because copper is a trace element that is essential for human health. All water wells have $\mathrm{Cu}^{+2}$ values ranging between $40 \mu \mathrm{g} / \mathrm{l}$ in well (No.1) and 52 $\mu \mathrm{g} / \mathrm{l}$ in well (No.2), where the guideline value for copper in drinking water is $1000 \mu \mathrm{g} / \mathrm{l}$ (WHO, 1984), while the guideline value for copper in irrigation water is $2000 \mu \mathrm{g} / 1$ (FAO, 1985).

Uranium (U) is considered as a toxic and radioactive element for human, the chemical toxicity of uranium is due to its combination in the hexavalent state with phosphate group on the cells surface in human body hence blocking normal metabolic processes necessary for cells survival. All well water have uranium values ranging between $120 \mu \mathrm{g} / 1$ in well (No.1) and 70 $\mu \mathrm{g} / \mathrm{l}$ in well (No.2), where the guideline value for uranium in drinking water is $120 \mu \mathrm{g} / \mathrm{l}$ (WHO, 1984) and $9 \mu \mathrm{g} / \mathrm{l}$ (EPA, 2002) hence the permissible limits of for drinking water does exceed.

\section{Conclusions}

Orange peels as cellulosic materials could be used economically for preparation of ion exchange resins. In general, orange peels were chosen as plant remains because they are popular, available and widespread plant wastes all over the world. The first main object of this study was to investigate the different organic resins synthesized from orange peels and testing their ability to adsorb uranium and associated elements. The second main object of this study was to determine the optimum factors controlling uranium adsorption by these produced resins. To achieve this goal, the chemical characterization of non treated Egyptian orange peels, a number of chemical studies were done to determine mineral and natural content different trials were accomplished to prepare the modified liginocellulosic orange peels using amines as well as chlorosulfonic acid, phosphorous oxychloride and mixture of both, whatever the orange peels were pretreated or not by soda. The prepared resins firstly characterized by IR, ESM and elements analyse. These exchange resins were applied for removing uranium and associated elements from Sinai water wells.

\section{REFERENCES}

Abdelhafez, A.A. and J. Jianhua (2016). Removal of $\mathrm{Pb}$ (II) from aqueous solution by using biochars derived from sugar cane bagasse and orange peel. J. Taiwan Inst. Chem. Eng., 61: 367-375.

Al-Saadi, N.H.M., N.S. Ahmad and S.E. Saeed (2009). Determination of some chemical compounds and the effect of oil extract from orange peel on some pathogens. J. Kerbala Univ Univ., 7 (2): 33-39.

Amin, M.T., A.A. Alazba and M.N. Amin (2017). Absorption behaviours of copper, lead, and arsenic in aqueous solution using date palm fibres and orange peel: kinetics and thermodynamics. Pol. J. Environ. Stud., 26 (2): 543-557.

AOAC (1984). Official Methods of Analysis. 14th Edn., Association of Official analytical chemists, Washington, DC., USA.

Chebotarev, I.I. (1955). Metamorphism of natural water in the crust of weathering. Geochem. Acta., 8:32-39

Cotteni, A. (1980). Soil and Plant Testing as Basis of Fertilizer Recommendation, Food and Agriculture Organization of the United Nations, Rom. No.38/2,118 pp.

Custodio, E. and G.H. Bruggman (1987). Spectrophotmetric method for the determination of radioactive elements. Talanta, $17: 15$ - 218

Dhakal, R.P., K.N. Ghimire and K. Inoue (2005) Adsorptive separation of heavy metal from 
an aquatic environment using orange waste, Hydrometallurgy, 79: 182-190 190.

ECAFE and UNESCO (1963). The Developments of Ground Water Resources With Special Reference to Deltaic Areas, United Nation, New York, USA, 5: 1-244

Egyptian Higher Committee of Water (EHCW), (1995). Standards for drinking and domestic uses.

El-Sheikh, E.M. (2006). Geochemical studies and uranium minerals concentration using organic surfactants from radioactive syenite rocks, El-Grra El-Hamra, Tushki area, South Western Desert, Thesis, Fac. Sci., Sci., Ain Shams Univ., Egypt.

El-Sheikh, E.M. (2013). Potentiality of uranium adsorption and its associated elements from waste laboratory liquids using black tea waste. Nuclear Sci. Sci. Scien. Sci. J., 2: 139152

EPA (2002). Environmental Protection Agency, National primary drinking water regulations. Radio nuclides, proposed rule. Fed- Regist. 56: 33050-33123.

Essawy, H.A. and H.S. Ibrahim (2004). Synthesis and characterization of poly (vinylpyrrolidoneco-methylacrylate) hydrogel for removal and recovery of heavy metal ions from wastewater. React. Funct. Polym., 61: 421-432.

FAO (1985). Water Quality for Irrigation and Drainage. New York, 29: 1-87

Feng, N.C. and X.Y. Guo (2012). Characterization of adsorptive capacity and mechanisms on adsorption of copper, lead and zinc by modified orange peel. T. Nonferr. Metal Soc. May, 22 (5): 1224-1231.

Feng, N.C., X.Y. Guoand and S. Liang (2009). Adsorption study of copper (II) by chemically modified orange peel. J. Hazardous Materials, 164: 1286-1292.

Gautam, R.K., S.K. Sharma, S. Mahiya and M.C. Chattopadhyaya (2014). Contamination of Heavy Metals in Aquatic Media: Transport, Toxicity and Technologies for Remediation. Royal Soc. Chem., i, (pp. 124), DOI: 10.1039/9781782620174-00001.
Hello, K.M., H.R. Hasan, M.H. Sauodi and P. Morgen (2014). Cellulose hydrolysis over silica modified with chlorosulfonic acid in one pot synthesis. Appl. Catalysis A: General, 475: 226-234.

Horrocks, A.R. and S. Zhang (2001). Enhancing polymer char formation by reaction with phosphorylated polyols.1.Cellulose, Polymer, 42: 8025-8033.

LalSrivastav, A. and M. Ranjan (2020). Chapter 1- Inorganic Water Pollutants. Inorganic Pollutants in Water. Elsevier : 1-15.

Li, X., Y. Tang, X. Cao, D. Lu, F. Luo and W. Shao (2008). Preparation and evaluation of orange peel cellulose adsorbents for effective removal of cadmium, zinc, cobalt and nickel, Colloids Surf. A: Physicochem. Eng. Asp., 317: 512-521.

Li, X., Y. Tang, Z. Xuan, Y. Liu and F. Luo (2007). Study on the preparation of orange peel cellulose adsorbents and biosorption of $\mathrm{Cd}^{2+}$ from aqueous solution. Separation and Purification Technol., 55: 69-75.

Liang, S., X. Guo, N. Feng and Q. Tian (2010). Isotherms, kinetics and thermodynamic studies of adsorption of $\mathrm{Cu}^{2+}$ from aqueous solutions by $\mathrm{Mg}^{2+} / \mathrm{K}^{+}$type orange peel adsorbents. J. Hazard Mater., 174: 756-762.

Loizidou, M. (2015). Waste management and symbiosis for waste valorization. Waste Biomass Valor, 6: 623-624

Morsy, A.M.A. (2003). Entrapment of some radioactive elements by some wild plants and the effect of their biochemical constituents, M.Sc. Thesis, Biochem. Dept., Fac. Agric., Ain Shams Univ., Egypt.

Muhammad, I.M., U.A. El-Nafaty and S. Abdulsalam (2012). Oil removal from produced water using banana peel. Nigerian Inst. Agric. Eng. Bauchi., 533-546.

Ning-Chuan, F., G. Xue-Yi and L. Sha (2010). Enhanced $\mathrm{Cu}$ (II) adsorption by orange peel modified with sodium hydroxide. Trans. Nonferrous Met. Soc. China., 20: 146-152.

Orabi, A.H., E.M. El-Sheikh, W.H. Saleh, A.O. Youssef, M.Y. El-Kady and Z.M. Shalaby (2016). Potentiality of uranium adsorption 
from wet phosphoric acid using amine impregnated cellulose. J. Radiation Rad. Res. and Appl. Sci., 9: 193-206.

Pankaj, S., B. Tanwar, S. Goyal and P.K. Patnala (2012). A comparative study of sonosorption of reactive red 141 dye on $\mathrm{tio}_{2}$, banana peel, orange peel and hardwood saw dust. J. Appl. Chem., 1 (4): 505-511

Park, S., R. Venditti, H. Jameel and J. Pawlak (2006). Changes in pore size distribution during the drying of cellulose fibers as measured by differential scanning calorimetry. Carbohydrate Polymers, 66 : 97-103

Quek, S.Y., D.A.J. Wase and C.F. Forster (1998). The use of sago waste for the sorption of lead and copper, Water SA, V., 24 (3): 251-256.

Ritcy, G.M. and A.W. Ashbrook (1982). Solvent Extraction Principals and Applications to Process Metallurgy, V.2, Elsevier Sci. Publishing Comp. Amsterdam.
Schiewer, S. and S.B. Patil (2008). Pectin-rich fruit wastes as biosorbents for heavy metal removal: equilibrium and kinetics. Biores. Technol., 99: 1896-1903.

Sciban, M., M. Kalasnja and B. Skrbic (2006). Modified softwood sawdust as adsorbent of heavy metal ions from water, J. Hazard. Mater., 136 (2): 266-271.

Sulekha, G. and G. Jaya (2018). Orange peel: a potential source of phytochemical compounds. Int. J. Chem. Tech. Res., 11 (02): 240-243.

TAPPI (1957). Technical Association of the Pulp and Paper Industry, www. Tappi, Org/ Index asp.

WHO (1984). World Health Organization. Recommendations in guideline for drinking water quality. WHO, Geneva, Switzerland.

WHO (1993). World Health Organization. Recommendations in guideline for drinking water quality. $2{ }^{\text {nd }}$ Ed ., Geneva.

\footnotetext{
إزالة اليورانيوم والعناصر المصاحبة من مياه آبار سيناء بإستخدام قشور البرتقال الجافة والمعالجة كيميائيًا

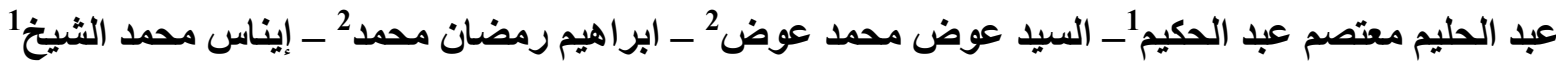
1- هيئة المو اد النووية ـ ص ـ ب 530 ـ المعادى ـ القاهرة ـ مصر 2- قسم علوم الأراضى - كلية الزر اعة - جامعة الزقازيق - مصر

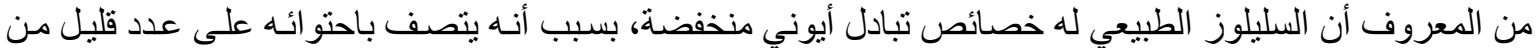

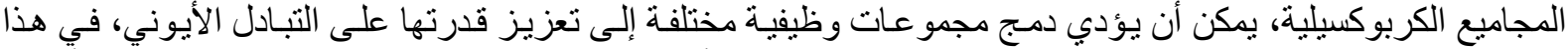

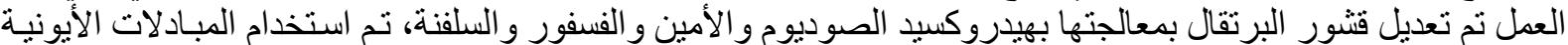

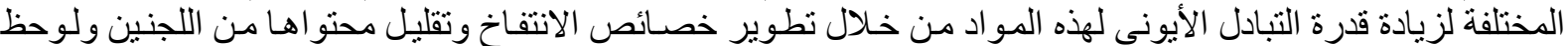

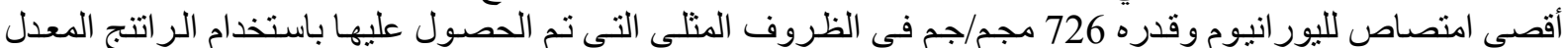

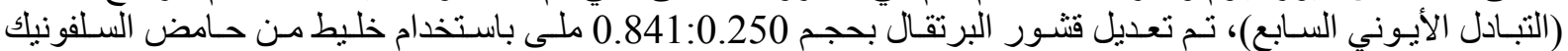

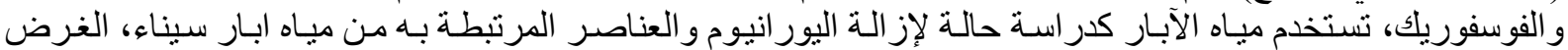

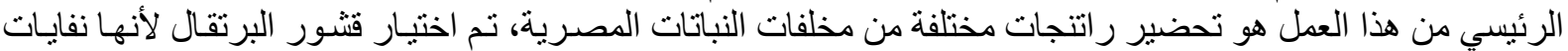
نباتية شائعة ومنتشرة في مصر.
}

$$
\begin{aligned}
& \text { أستاذ الكيمياء المتفر غ - كلية العلوم - جامعة الزقازيق. } \\
& \text { أستاذ الأر اضي ـ كلبة الزر اعة - جامعة الزقازيق. }
\end{aligned}
$$
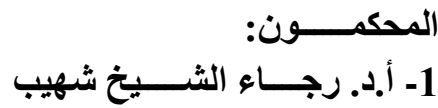

2- 2 - 2. أ.د. السيد أحمد حسن الناقة 
